\title{
WPŁYW WARUNKÓW NATURALNYCH NA SŁUŻBĘ FORMACJI TYŁOWYCH WOJSKA POLSKIEGO W CZASIE WOJNY POLSKO-SOWIECKIEJ W LATACH 1919-1921
}

\begin{abstract}
Streszczenie. W poniższym artykule przedstawiono wpływ warunków terenowych na służbę i kondycję żołnierzy stacjonujących na zapleczu frontu, w tzw. obszarze etapowym. Zaprezentowano również problem chorób zakaźnych trapiących żołnierzy pełniących służbę na zapleczu frontu. Praca opiera się przede wszystkim na materiałach archiwalnych z okresu wojen o granice Polski odrodzonej w latach 1919-1921 dostępnych w Centralnym Archiwum Wojskowym w Warszawie, a wytworzonych przez Dowództwa Okręgów Etapowych i Dowództwa Powiatów Etapowych oraz na literaturze.
\end{abstract}

Słowa kluczowe: wojna polsko-sowiecka, warunki służby, pogranicze, wojska etapowe

Tematem prezentowanej pracy jest wpływ warunków naturalnych na służbę żołnierzy polskich pełnioną na zapleczu frontu wojny polsko-sowieckiej. Problematyka warunków służby żołnierzy formacji tyłowych jest stosunkowo rzadko podejmowana w badaniach nad historią wojskowości początku XX w. Podstawowe publikacje dotyczące tego zagadnienia to prace Janusza Odziemkowskiego ${ }^{1}$. Skarbnicą wiedzy o służbie i kondycji pełniących ją żołnierzy są opublikowane drukiem pamiętniki uczestników wojen o granice odrodzonej Polski. Są to przede wszystkim prace autorstwa stosunkowo dobrze wykształconych

1 J. Odziemkowski, Polskie formacje etapowe na Litwie i Biatorusi 1919-1920, Kraków 2011; IDEM, Piechota polska w wojnie z Rosja bolszewicka 1919-1920, Warszawa 2010. 
żołnierzy i oficerów jednostek liniowych. Autor w swoich badaniach nie dotarł do wspomnień szeregowych żołnierzy wojsk wartowniczych i etapowych, które byłyby dla poniższego artykułu szczególnie cenne. Pamięć o czynach bojowych i zwycięstwach kultywowali żołnierze jednostek frontowych, które na szlaku wojennym wytworzyły swój żołnierski etos. Oddziały tyłowe pełniły służbę ciężką i niewdzięczną, ale nie było im dane odnosić nad nieprzyjacielem spektakularnych zwycięstw. Stąd też nie chwalili się swoją służbą odbytą w czasie walk o granice. Poza tym formacje tyłowe wcielały żołnierzy o niższych kwalifikacjach przewidując, że nie będą zmuszeni do stawienia nieprzyjacielowi bezpośrednio czoła. Nawet oficerowie o znacznych zasługach bojowych i doświadczeniu byli wcielani do formacji tyłowych, gdy byli inwalidami lub kończyli rekonwalescencję po otrzymanych ranach.

Od zarania dziejów przyroda w istotny sposób oddziaływała na przebieg działań zbrojnych. Miała również wpływ na warunki służby wojskowej pełnionej na tyłach frontu. Żołnierze formacji liniowych, mający bezpośredni kontakt z nieprzyjacielem, w znacznie większym stopniu zależeli od sił przyrody. Przebywali na linii frontu w okopach, wystawieni na oddziaływanie pogody, niewygód i chorób. Ciężar służby na froncie potęgowały dodatkowo braki w zaopatrzeniu w artykuły pierwszej potrzeby i wyposażeniu w podstawowy żołnierski ekwipunek. Na negatywny wpływ otoczenia narażeni byli również żołnierze pełniący w potocznej opinii służbę bezpieczną na zapleczu frontu, w tym w tzw. etapach. Trudy codziennej służby wojsk etapowych z pewnością były mniejsze niż na froncie, ale tu również przyroda miała wpływ na codzienną egzystencję żołnierzy. $Z$ powodu specyfiki samej formacji czy podejścia do niej wyższych władz wojskowych mogli oni odczuwać trudy codziennej służby w sposób odmienny, stykali się bowiem z innymi czynnikami niż żołnierze formacji liniowych.

$\mathrm{Na}$ realia służby wojskowej w znacznym stopniu wpływają warunki terenowe, w tym rzeźba terenu, na którym prowadzone są działania zbrojne. Sam wpływ wysokości bezwzględnych na funkcjonowanie człowieka pojawia się w zasadzie przy wysokościach powyżej 2000 m n.p.m. Wówczas ze zmianami ciśnienia atmosferycznego ujawnia się stopniowe osłabianie organizmu ludzkiego ${ }^{2}$. Wojny o granice Polski odrodzonej toczyły się na obrzeżach ziem polskich. Żadne walki nie rozgrywały się w wysokich górach, na wysokości która wpływałaby negatywnie na ludzki organizm. Natomiast dla formacji

\footnotetext{
2 Z. Parucki, Geografia polityczna i wojenna, Warszawa 1979, s. 17.
} 
etapowych pełniących służbę w Karpatach, tereny górskie stanowiły rzeczywiście poważne utrudnienie. Służba patrolowa, czynności asystencyjne, np. przy rekwizycjach, a szczególnie pacyfikacje czy ekspedycje karne wiązały się z długimi przemarszami w trudnym, pozbawionym dróg terenie. Oddziały te rzadko dysponowały samochodami, zaprzęgami czy choćby samymi końmi, chociaż w ich etatach środki transportowe były przewidziane. Często jedynym środkiem łączności między posterunkami wartowniczymi, czy nawet niższymi dowódcami, był pieszy goniec przemierzający z meldunkami trasę 20, a nawet więcej kilometrów w jedną stronę.

Front wojny polsko-sowieckiej rozciągał się wzdłuż wschodniego pogranicza ziem Rzeczypospolitej. Były to zachodnie kresy byłego imperium rosyjskiego i północno-wschodnie byłych Austro-Węgier. Z powodów militarnych, ale również gospodarczych, obszary te były zaniedbane pod względem komunikacyjnym. Brakowało linii kolejowych, a drogi gruntowe często nie nadawały się do użytku. Szczególnie dotyczyło to Polesia i Wileńszczyzny, gdzie w czasie I wojny światowej układane przez wojsko niemieckie drewniane trakty z okrąglaków po prostu zbutwiały i nie tylko przestały odgrywać swą rolę, ale stanowiły dla maszerujących po nich ludzi zagrożenie. Interesującym obszarem było Pokucie i ziemia stanisławowska, mająca zróżnicowaną rzeźbę terenu, od wyżyn po górskie rejony wschodnich Karpat. Zwłaszcza rejon Karpat był pozbawiony dróg, więc w okresie jesienno-zimowym i wczesną wiosną część obszaru np. Pokucia była bardzo trudno dostępna. Na przykład w listopadzie 1919 r. wezbrany Czeremosz zerwał mosty łączące Uścieryki ze Stebną i most między Kutami a Wyżnicą, odcinając znajdujące się tam pododdziały wojskowe od ich garnizonów ${ }^{3}$.

Dodatkowym utrudnieniem w pełnieniu służby wojskowej były obszary leśne. Działania w lesie stanowią bardzo wyczerpujący nie tylko fizycznie, ale również psychicznie rodzaj walki. Formacje etapowe zajmowały się zwalczaniem oddziałów dywersyjnych oraz zwykłych band rabunkowych. Na terenach gęsto pokrytych lasami i bagnami odrywające się od zwartych oddziałów sowieckich grupy żołnierzy stawały się szybko bandami rabunkowymi zasilanymi często przez miejscowych rzezimieszków (nie zawsze będących zawodowymi bandytami).

\footnotetext{
${ }^{3}$ Centralne Archiwum Wojskowe, Wojskowe Biuro Historyczne [dalej: CAW WBH], Dowództwo Powiatu Etapowego Kołomyja, sygn. I.332.60.1, Dowództwo Okręgu Etapowego Lwów. Sytuacja bezpieczeństwa z dnia 19 XI 1919.
} 
Mniejsze grupy dywersantów bolszewickich działały również na obszarze przyfrontowym zagrażając nawet silnym oddziałom wojskowym. Szczególnie niebezpieczne były obszary leśne. Podczas walki na froncie w okolicach Kamienia Koszyrskiego gen. Stanisław Bułak-Bałachowicz przeprawiając się z oddziałem przez las mówił: „W tym lesie możemy mieć zasadzkę. Las [jest] duży, dookoła lasu bagna. Kapitalne miejsce na ukrycie się bolszewickich band dywersyjnych. Mimo ostrożnego marszu - możemy mieć niespodziankę. Ale nie ma co. Maszerujemy”4.

Przykładem zwalczania band dywersyjnych był pościg za grasującą zimą 1920 r. w powiatach borysowskim i wilejskim szajką bandytów. Patrole żandarmerii po dwudniowych bezskutecznych poszukiwaniach powróciły do swych garnizonów uznając, że banda przeniosła się do stałych kryjówek wyruszając do innych powiatów na grabież. Przeprowadzono kolejną obławę w dwóch wsiach w powiecie borysowskim. Po dziesięciu dniach w pięciu gminach schwytano tylko jednego przestępcę przekonując się, że w trudnym terenie niewielki oddział żandarmerii nie jest w stanie zlikwidować bardzo ruchliwej bandy. Wcześniej organizowano nie przynoszące efektu bezładne obławy żandarmerii w poprzednich miejscach zamieszkania poszukiwanych kryminalistów. Ci chronili się w wielkich kompleksach leśnych w specjalnie budowanych ziemiankach. Ustalono, że szajkę bandytów tworzyła grupa 30 kompletnie umundurowanych i uzbrojonych osób. Ukrywając się w lasach grupa przestępcza działała nawet jako oddział konny5. Las, szczególnie w niskich górach, stanowił dobrą osłonę dla dużych oddziałów partyzanckich. Wiosną 1920 r. wybuchło inspirowane przez bolszewików powstanie rusińskich chłopów przeciwko „polskiej okupacji”. Do zbrojnego przewrotu bolszewiccy agitatorzy wzywali zamieszkałych w Kosowie i Żabiem Hucułów. W dniu 17 kwietnia 1920 r. około godziny 23.00 mniej więcej stuosobowa grupa chłopów uzbrojona w sześć karabinów bezskutecznie próbowała rozbroić posterunek polskiej żandarmerii w Żabiem. Oddział partyzancki, liczący prawdopodobnie nawet sześćset osób, uzbrojonych w karabiny, kosy, siekiery czy granaty ręczne, miał stacjonować na górze Płajik. Buntownicy oczekiwali tam na rewolucję mającą rzekomo wybuchnąć w dniu 18 kwietnia

${ }^{4}$ S. Lis-BŁoński, Batachowcy. Notatki oficera tącznikowego przy Ochotniczej Armii Sprzymierzonej z frontu wojny polsko-bolszewickiej 1920 roku, wstęp i oprac. G.J. PeLICA, Kraków 2013, s. 133.

5 CAW WBH, DOE Mińsk 1 „b” 1. 331. 12.1 Dowództwo Oddziału Żandarmerii Polowej Wojsk Polskich w Mińsku Litewskim, Mińsk dn. 23 III 1920. Do Okręgu Etapowego w Mińsku. 
1920 r. w całej Polsce. Wskutek rozruchów na obszarze Huculszczyzny wprowadzono sądy doraźne skazujące zatrzymanych buntowników na karę śmierci. Przeprowadzono również pacyfikacje i ekspedycje karne ${ }^{6}$.

Na początku 1920 r. na Wołyniu, pomimo poprawy stanu bezpieczeństwa, na mocno zalesionych obszarach północnej części powiatu rówieńskiego działały bandy, których liczebność oceniano łącznie nawet na 500 osób. Kryminaliści posiadali dobre uzbrojenie i wojskowy ekwipunek. W rejonie posterunku Wysock działały dwie bandy rabunkowe liczące po około 40 ludzi. Każda z nich według cytowanego raportu sytuacyjnego dysponowała nawet karabinem maszynowym. Ciągłe niebezpieczeństwo groziło mieszkańcom gminy Dziatkowicze, do której dla ochrony przed przestępcami wysłano na stałe podoficera i 10 szeregowych z 4 kompanii II lubelskiego batalionu etapowego. Ludność powiatu rówieńskiego była podatna na antypolską agitację. Mieszkańcy powiatu sympatyzowali z ruchem wszechrosyjskim, ukraińskim nacjonalizmem i bolszewizmem 7 . Las dawał więc schronienie dużym bandom dywersyjnym czy popełniającym pospolite przestępstwa kryminalistom, a przeszukanie obszaru leśnego wymagało znacznych, nie zawsze dostępnych, nakładów sił i środków.

Bliskość obszarów leśnych w okresie zimowym bywała często „zbawienna” dla żołnierzy stacjonujących w chłodnych porach roku w zimnych, nieogrzewanych kwaterach. Czasami zaopatrywali się w opał w lasach pozyskując go w sposób niezgodny z prawem. Na przykład z leśnictwa powiatu wołkowyskiego spływały skargi, że niektóre polskie oddziały wojskowe samowolnie udawały się do lasów państwowych, skąd - zmuszając do pomocy straż leśną - bez pozwolenia pozyskiwały drewno. Wywożono nie tylko drewno opałowe, ale również rąbano cenne drewno budowlane ${ }^{8}$.

Żołnierze oddziałów pełniących służbę na zapleczu frontu lub na granicy musieli zmierzyć się z problemem dużych przestrzeni. W czasie wojny stosunek liczby żołnierzy do obszaru jest istotny nie tylko w skali strategicznej, ale również taktycznej. W skali taktycznej regulaminy walki określają, jaka szerokość, a więc przestrzeń, jest najodpowiedniejsza dla wykonania zadań bojowych. Stosunek

6 T. Biernacek, Nad Prutem i Czeremoszem, cz. 1: 1914-1928, Zielona Góra 1992, s. 2627.

7 CAW WBH, DPE Równe 1, sygn. I 332. 78.1, Ekspozytura Żandar. Pol. w Równie, Raport sytuacyjny od dnia 10 stycznia do 20 stycznia 1920 r. Bandy rabunkowe były uzbrojone w broń wojskową pozostałą po walkach I wojny światowej i wojny polsko-sowieckiej z lat 1919-1921.

${ }^{8}$ CAW WBH, DOE Wołkowysk 2, sygn. I.331.23.2, Dowództwo Powiatu Etapowego Wołkowysk 5 VI 1919 do wszystkich oddziałów rozkwaterowanych w mieście Wołkowysku. 
liczby żołnierzy do przestrzeni jest ważny również ze względów psychologicznych. Żołnierz odpowiedzialny za zbyt duży wycinek terenu nie jest w stanie właściwie wypełnić swoich zadań. Na posterunku czuje się przytłoczony, bezradny i samotny'.

Przestrzeń odgrywa niezwykle istotną rolę w działaniach wojsk wartowniczych i etapowych z racji zadań, jakie tym wojskom wyznaczano. Problemy z obsadzeniem linii granicznej były widoczne na granicy między Litwą Środkową a Litwą Kowieńską, gdzie ochrona granicy z powodu niewielkiej liczby żołnierzy była niewystarczająca. Najgorzej prezentował się odcinek obsadzony przez ułanów, gdyż ci nie pełnili służby zgodnie z rozkazami, motywując to tym, że nie mogą odbywać pieszych patroli, a dla patroli konnych nie dysponują końmi. Z powodu braku obuwia część żołnierzy nie była w stanie pełnić straży m.in. w rejonie II Stacji Kontrolnej w Burkielach. Lepiej umundurowani żołnierze pełnili służbę z dużym zaangażowaniem, ale mało skutecznie, ponieważ posterunki były rozmieszczone zbyt daleko od siebie. VI Stacja Kontrolna nr 6 w Sejmanach tworzyła 4 placówki o sile 12 ludzi obsadzając nimi kordon na przestrzeni $10,7 \mathrm{~km}$. Wobec zamarznięcia jezior w rejonie stacji i rzadkiej obsady kordonu wojskiem, podróżujący omijali stację kontrolną i przez zamarznięte jeziora jeździli do Trok. Pilnujące granicy wojsko nie było w stanie kontrolować ani samych podróżnych, ani tego, co ze sobą przewozili. Obsadzona siecią placówek kontrolnych granica w rzeczywistości zimą była otwarta. Rejon VII Stacji Kontrolnej w Rudziszkach rozciągał się na odcinku 27 km. Służbę na tym kordonie pełniła jedna kompania piechoty (30\% ludzi nie miało butów) oraz szwadron 10 pułku ułanów w sile 80 szabel. Na kordonie rozmieszczono placówki oddalone od siebie o 5-6 km, obsadzone przez 4-5 żołnierzy. Placówki te pełniły służbę (zwłaszcza kawaleryjskie) od godziny 8 rano do północy. Nocą żołnierze spali pozostawiając kordon bez nadzoru. Ułani nie wysyłali patroli wcale, gdyż według słów dowódcy szwadronu mieli rozkaz nie męczyć koni, a „kawaleria pieszo nigdy nie chodziła i chodzić nie będzie” 10 .

Na Litwie specyficzne trudności w pełnieniu obowiązków wystąpiły w rejonie IX Stacji Kontrolnej w Matuzach. Rejon ten również był niedostatecznie obsadzony wojskiem. Cywilni agenci - wywiadowcy policji - z powodu braku

\footnotetext{
9 Z. PARUCKI, op.cit., s. 16-17.

${ }^{10}$ R. Roguski, The protection of the cordon section on the border between Central Lithuania and the so-called Kaunas Lithuania between 1921-1923, „Historia i Świat” 2018, nr 7, s. 256.
} 
broni palnej nie mogli pełnić służby, zwłaszcza w rejonie miejscowości Sejmany, gdzie nocą wilki porywały trzodę chlewną. Agenci obawiali się dzikich zwierząt. Na ziemiach białoruskich tego typu problem miała czasami kawaleria, która odmawiała służby wartowniczej na placówkach położonych obok lasu, ponieważ wilki atakowały konie. Na Białorusi w czasie śnieżnej zimy $1919 \mathrm{r}$. drapieżniki te kilkukrotnie zaatakowały polskie patrole i podkopywały się do owczarni. W okolicy Mściża nad Berezyną nad jeziorem Pelik (koło dawnej Grobli Napoleońskiej) wilki zagryzły dwóch ułanów wraz z końmi. Od czasu tamtego zdarzenia posterunki alarmowe zamiast ułanów trzymali chłopi z widłami, gdyż drapieżniki wyczuwały od ułanów zapach końskiego potu i zaciekle ich atakowały ${ }^{11}$. Prawdopodobnie pełniący służbę na zasadzie świadczeń osobistych cywile posiadali broń palną, ale była ona nielegalna, więc z obawy przed konsekwencjami karnymi, w tym karą śmierci, uzbrajali się jedynie w narzędzia gospodarskie. Napaści wilków na ludzi zdarzały się niemal od zawsze. W latach 1870-1887 w 49 guberniach europejskiej części Cesarstwa Rosyjskiego wilki zabiły 1445 osób. Dokumenty administracyjne Wielkiego Księstwa Poznańskiego z początku XIX w. mówią o dziesiątkach osób zagryzionych przez te drapieżniki. W okresie bliższym tematyce prezentowanego artykułu, bo w czasie międzywojnia polska prasa donosiła o licznych atakach wilków na ludzi, a nawet o regularnych potyczkach, jakie patrole polskich formacji granicznych toczyły z liczącymi kilkadziesiąt osobników watahami. Do takich doniesień należy podchodzić z dużą dozą ostrożności. Natomiast zdarzały się w historii ziem polskich liczne okresy, w których człowiek prowadzący wojny dostarczał wilkom dużej ilości żeru w postaci niepogrzebanych zwłok czy końskiej padliny ${ }^{12}$. W warunkach łatwiejszego dostępu do pokarmu drapieżniki zwiększały swoją populację. Po zakończeniu walk populacja wilków utrzymywała się na podobnym poziomie jak w czasie wojny, a pokarmu zaczynało brakować. Zwierzęta stawały się więc poważnym zagrożeniem dla ludzi.

Rola przestrzeni była szczególnie widoczna w przypadku ochrony linii kolejowych i kordonowych, gdzie niewielki oddział miał do obsadzenia długie odcinki torów. Z braku wystarczających sił uciekano się do wykorzystania ludności cywilnej na zasadzie osobistych świadczeń wojennych. Na wschodnim

${ }^{11}$ S. Mirek, Opowieści Legionisty. Wspomnienia nie tylko frontowe spisane przez uczestnika walk w Legionach Pitsudskiego, Pruszków 1994, s. 127.

${ }^{12}$ H. OKarma, Wilk. Monografia przyrodniczo-towiecka, Białowieża 1992, s. 145. 
pograniczu w warunkach społeczeństwa wielonarodowego lojalność lokalnych mieszkańców była dyskusyjna, więc takie świadczenia należało podeprzeć groźbą drakońskich kar, z karą śmierci dla sołtysa i spaleniem wsi włącznie ${ }^{13}$.

Żołnierze formacji tyłowych byli zagrożeni chorobami w większym stopniu niż wojska operacyjne. Poważnym problemem były m.in. dolegliwości, na które byli narażeni obcując z ludnością cywilną, w tym z uchodźcami i jeńcami kierowanymi z frontu przez obszar etapowy do obozów jenieckich. Ogólna nędza, złe wyżywienie, niedostatecznie rozwinięta opieka medyczna i nieprzestrzeganie zasad higieny tworzyły zespół czynników sprzyjających rozprzestrzenianiu się chorób zakaźnych i lokalnych epidemii. Istniało więc duże prawdopodobieństwo przeniesienia epidemii od ludności cywilnej w szeregi wojska. Gdy żołnierze kwaterowali w prywatnych domach zagrożenie rosło jeszcze bardziej. Brakowało środków czystości oraz powszechnego przekonania o konieczności ich stosowania. Oszczędzano mydło gotując w jednym kotle odzież należącą do kilku żołnierzy. Takie zabiegi niszczyły mundury, ale też zabijały insekty. Raz w tygodniu żołnierze szli do łaźni, ale obciążenie służbą etapową było na tyle duże, że nie wszyscy mogli korzystać z takiego „luksusu”. Pomimo częstych instrukcji o zasadach higieny i wysiłków lekarzy wojskowych do oddziałów przedostawały się takie choroby, jak tyfus plamisty, biegunki czy nawet czerwonka ${ }^{14}$. Pełniący służbę $w$ górskich rejonach Pokucia polscy żołnierze narzekali na zawszenie, a dezynfekcja brudnych mundurów z powodu braku zastępczych ubrań była niewykonalna ${ }^{15}$. W końcu października 1919 r. stan obsady wojsk etapowych na Pokuciu był na tyle niski, że służbę wartowniczą żołnierze pełnili po $10 \mathrm{dni}$ z rzędu bez odpoczynku. Nie było kim ich zastąpić, więc zabiegów odwszawiania w ogóle nie przeprowadzano ${ }^{16}$.

$\mathrm{Na}$ Pokuciu w roku 1919 stan zdrowotny stacjonującego tam polskiego wojska był zadowalający. Sporadyczne przypadki tyfusu osutkowego meldowano przede wszystkim z powiatu kosowskiego (Żabie). Szerzyły się jednak choroby

13 R. Roguski, Bezpieczeństwo linii kolejowych na obszarze etapowym Galicji w czasie wojny polsko-ukraińskiej o Galicję Wschodnią w roku 1919, „Studia Historyczno-Wojskowe” 2015, t. 6, s. 135-146.

14 J. Odziemkowski, Polskie formacje..., s. 67-68.

15 CAW WBH, DPE Kosów 1, sygn. I.332.61.1; Dowództwo Powiatu Etapowego Kosów L. 97. Raport sytuacyjny Dowództwa powiatu etapowego w Kosowie.

16 CAW WBH, Dowództwo Powiatu Etapowego Kołomyja, sygn. I.332.60.1; Dowództwo Etapu Pokucie L. Pf 408 do Dowództwa Okręgu Etapowego Lwów Sytuacja bezpieczeństwa z dnia 23 X 1919 r. 
weneryczne, co szczególnie dotyczyło dyslokowanych w regionie jednostek armii gen. Józefa Hallera. Spośród wszystkich żołnierzy zgłaszających się do izby chorych $20 \%$ to przypadki zakażonych wenerycznie. W celu zwalczania tych chorób często prowadzono rewizje u zarejestrowanych zawodowych lub tajnych prostytutek $^{17}$. Autor prezentowanego artykułu nie dotarł do materiałów ukazujących skuteczność akcji przeciw prostytucji prowadzonej na ziemi stanisławowskiej i na Pokuciu, gdzie przez długi czas stacjonowały wojska etapowe. W garnizonach wojskowych takie działania przeciwko „córom Koryntu”, bez ich zatrzymania oraz izolacji, nie mogły przynieść oczekiwanego skutku. Poza tym choroby weneryczne były rozpowszechnione w wielu regionach na pograniczu, więc źródłem zakażenia nie musiały być jedynie zawodowe prostytutki, ale też mieszkańcy, u których kwaterowali żołnierze.

Po poprawie stanu umundurowania poziom zdrowia żołnierzy na Pokuciu, w szczególności w garnizonie Kołomyja, był zadowalający. Stacjonujące tam kompanie wykazywały niewielką liczbę chorych, przeciętnie 100, dopiero w dekadzie od 10 do 21 stycznia liczba zgłaszających się do lekarza wzrosła do 120. Narzekający na swoją kondycje żołnierze byli chorzy naprawdę. Przeważały dolegliwości układu oddechowego od kataru po zapalenie oskrzeli. Podejrzanych o gruźlicę oraz ciężkie przypadki grypy odsyłano do szpitala. Łóżka izby chorych były stale zajęte. Kilka osób podejrzewano o tyfus. Szerzyły się choroby weneryczne, szczególnie w garnizonie kołomyjskim. Z batalionu etapowego odsyłano chorych do szpitala wenerycznego w Kołomyi, a ten odsyłał ich z powrotem do batalionu. Chorych wenerycznie nie kierowano do szpitala w Stanisławowie, bo ten był również przepełniony i stamtąd zakażonych odsyłano także z powrotem do batalionu. Takie odsyłanie narażało skarb państwa na koszty, a bataliony na obniżenie wartości bojowej z powodu wysyłania żołnierzy zarażonych wenerycznie do służby wartowniczej i asystencyjnej. W garnizonie kołomyjskim z obawy przed epidemią co dwa tygodnie przeprowadzano dezynfekcję. Brakowało odwszalni i pralni. Z rozkazu Dowództwa Frontu Podolskiego Dowództwo Powiatu Etapowego Pokucie powołało do życia Komisję Zdrowotną dla mieszkańców Kołomyi, w której skład weszli członkowie władz wojskowych i politycznych. Pierwszą czynnością Komisji Zdrowotnej było podjęcie się zwalczania chorób epidemicznych szerzących się w Kołomyi. Zarządzono czasowe zamknięcie kin, restauracje zaś i kawiarnie otwierano tylko

${ }^{17}$ CAW WBH, Dowództwo Etapu Pokucie i Kołomyja, sygn. I.330.2.1. 
w porze obiadowej. Uruchomiono łaźnię publiczną, żeby mogły z niej korzystać również osoby cywilne, chroniąc się przed tyfusem. Jak wszędzie, brakowało personelu medycznego, przede wszystkim lekarzy. W ramach działań profilaktycznych dr Jaworski wygłosił dla żołnierzy garnizonu wykład „O chorobach wenerycznych"18. W celu tłumienia zarazy tyfusu dowództwo wspólnie z władzami cywilnymi prowadziło akcję „kąpieli ludowych”, za którą odpowiedzialny był szef sanitarny kpt. dr Zwybel ${ }^{19}$.

W pierwszym kwartale 1920 r. na pograniczu opanowanie epidemii tyfusu utrudniał brak pomocy medycznej oraz niesumienność praktykujących tam lekarzy. W okolicach Lwowa za odwiedzenie chorego medycy potrafili żądać po 1000 koron, na co ludność uboższa nie mogą sobie pozwolićp ${ }^{20}$. Stacja etapowa Kuty donosiła o szerzeniu się tyfusu i szkarlatyny głównie wśród dzieci. Z tego powodu zarządzono zamknięcie szkół.

$\mathrm{Na}$ obszarze Białorusi w garnizonie mińskim do Ambulatorium Garnizonowego przychodziło bardzo dużo żołnierzy z kompanii instruktorskiej, chorych na choroby skórne. Dnia 14 lutego 1920 r. lekarz wizytował kompanię zamieszkałą w dawnym szpitalu wojskowym przy ul. Szpitalnej. Bardzo źle ubrani żołnierze mieszkali w nieopalanych izbach bez łóżek ani ław. Cały dzień spędzali na słomianych pryczach, spali też na słomie, a z braku stołów jedli na tej samej słomie. Brakowało świeżego mięsa i jarzyn, więc jedzono cały czas konserwy, co skutkowało rozwojem szkorbutu. Dawne wychodki w budynku były nieczyszczone i nie odseparowane od reszty pomieszczeń, więc na korytarzu panował brud. Nowe ubikacje zorganizowano w ogrodzie szpitalnym ${ }^{21}$.

Pełniącym służbę na pograniczu żołnierzom brakowało dosłownie wszystkiego. Często dochodziło do rekwizycji cywilnej odzieży na potrzeby wojska, ponieważ w formacjach etapowych pełniących służbę między innymi w Galicji

${ }^{18}$ CAW WBH, DPE Kołomyja 1 sygn. I.332.60.1 L. pf 132 Raport sytuacyjny do Dowództwa Okręgu Etapowego Kołomyja, 31 stycznia 1920 r. we Lwowie.

19 CAW WBH, Dowództwo Okręgu Etapowego Lwów, Sytuacja bezpieczeństwa z dnia 29 listopada 1919.

${ }^{20}$ Państwowe Archiwum Obwodu Lwowskiego we Lwowie, Lwowskoje wojewodskoje uprawle-

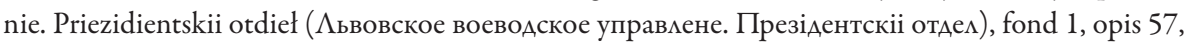
sprawa 28. Komenda Policji Państwowej na Małopolskę Sprawozdanie sytuacyjne za marzec 1920. We Lwowie, dnia 8 kwietnia 1920, s. 8, k. 75.

${ }^{21}$ CAW WBH DOE Mińsk 1 „d” Sygn. I.331.12.1 Lekarz Garnizonowy m. Mińsk - Lit. Dnia 15 II 1920 r. L. 56 Do Szefa Sanitarnego DOE. 
Wschodniej na porządku dziennym było pełnienie przez kilku żołnierzy na zmianę warty w jednej parze butów i jednym płaszczu ${ }^{22}$.

Czasami więc żołnierze wojsk etapowych nie tylko nie posiadali regulaminowych spodni czy bluz, ale brakowało im również odpowiedniego obuwia. Z powodu braku płaszczy i koców dokuczało im zimno. Przysyłane z Intendentury części umundurowania nie pokrywały dostatecznie zapotrzebowania ${ }^{23}$. Mundury często kradziono, a ich pojedyncze elementy odsprzedawano handlarzom. Sami dowódcy nie uczyli żołnierzy poszanowania wyposażenia i odzieży ${ }^{24}$. Na obszarze powiatu etapowego Kosów w stanowiącej jego obsadę kompanii etapowej ponad 50 żołnierzy nie posiadało żadnego obuwia ${ }^{25}$. Umundurowanie i bielizna pozostawiały wiele do życzenia i wymagały ciągłej staranności przełożonych ${ }^{26}$. W grudniu 1919 r. dowódcy odcinków wartowniczych na Pokuciu meldowali, że jeśli zaprowiantowanie oddziałów będzie w dalszym ciągu nieregularne, nie biorą odpowiedzialności za stan dyscypliny podległych im pododdziałów ${ }^{27}$.

Sytuacja niewiele się zmieniła nawet po zakończeniu walk o granice. $\mathrm{Na}$ kordonie między Litwą Środkową a tzw. Litwą Kowieńską braki w umundurowaniu nadal uniemożliwiały żołnierzom pełnienie służby. Ze względu na oszczędności wprowadzone przez Ministerstwo Skarbu Rzeczypospolitej, dowództwo odcinka kordonowego między tymi obszarami, nie mogąc otrzymać ekwipunku zimowego dla żołnierzy nie było w stanie obsadzić należycie linii demarkacyjnej ${ }^{28}$.

Warunki zakwaterowania żołnierzy pełniących służbę na obszarze tyłowym były zróżnicowane i na ogół pozostawiały bardzo wiele do życzenia. Baza koszarowa była często bardzo zdewastowana przez wycofujących się na przełomie 1918 i 1919 r. Niemców (oddziały stacjonowane na obszarze dawnego Ober-Ost) i przybyłych w ślad za nimi czerwonoarmistów. W niektórych

22 R. Roguski, Bezpieczeństwo linii..., s. 201.

23 CAW WBH, Dowództwo Etapu Pokucie i Kołomyja, sygn. I.330.2.1.

${ }^{24}$ CAW WBH, Batalion Wartowniczy 4/IV Kołomyja, sygn. I.333.134.1, Dowództwo Baonu wart. IV. Rozkaz nr 28, Kołomyja, 1 II 1920 r.

${ }^{25}$ CAW WBH, DPE Kosów 1 sygn. I. 332. 61.1, Dowództwo Powiatu Etapowego Kosów L. 97 Raport sytuacyjny Dowództwa powiatu etapowego w Kosowie.

26 J. Romer, Pamiętniki, Warszawa 2011, s. 203.

${ }^{27}$ CAW WBH, DPE Kosów 1 sygn. I.332.61.1, do Dow. Pokucie. Meldunek syt. wieczorny. Brak daty. Dowódca grupy taktycznej L.P. 869 Jaruzelski major.

${ }^{28}$ R. Roguski, The protection of the cordon..., s. 256. 
miastach, w których stacjonowały polskie oddziały wojskowe, nie było żadnych koszar ani innych obiektów wojskowych. Tymczasowe kwatery trzeba było urządzać w prowizorycznych nieopalanych barakach lub innych budynkach ${ }^{29}$. W Wilejce koszary mieściły się w prywatnych domach. Mieszkający w brudnych pomieszczeniach żołnierze spali na gołych deskach ${ }^{30}$. W położonych w Mińsku koszarach tzw. czerwonych przy ul. Nowo-Koszarowej stróż informował, że zakwaterowani tam żołnierze z mińskiego batalionu rozbierali puste baraki na opal. Wielokrotnie meldowano o tym komendantowi batalionu, który odpowiedział, że za karygodne działania mieszkających tam żołnierzy będzie osobiście odpowiadał stróż koszar ${ }^{31}$.

Żołnierze 4 Pułku Piechoty Legionów skierowani w końcu stycznia 1919 r. na Śląsk Cieszyński, rozmieszczeni wzdłuż granicy w okolicy Zwardonia, budowali dla siebie kwatery m.in. w górach, z dala od osiedli ludzkich. Wykopali w spadzistym stoku wnęki nakryte gałęziami. Następnego dnia żołnierzy z górskich placówek odwołano i rozkwaterowano w położonych u stóp gór wioskach. Patrolujący tylko pas graniczny żołnierze nie dysponowali kuchniami ani nie otrzymywali zaprowiantowania. Żywili się głównie jajkami, bo były najtańsze i najłatwiej dostępne ${ }^{32}$.

Dużym zagrożeniem dla zdrowia żołnierzy i ludności cywilnej były warunki sanitarne panujące w miejscowościach, w których stacjonowały oddziały wojskowe. W większości wypadków otoczenie domów zajętych przez wojsko było bardzo zanieczyszczone. Zaleganie zwałów śmieci wiosną i latem oprócz problemu insektów mogło skutkować wybuchem epidemii czerwonki, a nawet cholery i tyfusu. Szefowie sanitarni oddziałów mieli zarządzić komisyjnie inspekcje domów zajmowanych przez oddziały wojskowe i pojedynczych żołnierzy, przykładnie karząc za niedociągnięcia ${ }^{33}$.

We Lwowie w latach 1918-1921 panowała bardzo zła sytuacja sanitarna, szczególnie na obrzeżach miasta. Na przedmieściach śmieci nie wywożono

29 J. Odziemkowski, Polskie formacje..., s. 67.

${ }^{30}$ CAW WBH, DOE Wilno 1, sygn. I.331.22.1, Dowództwo Okręgu Etapowego Wilno. Rozkaz tajny nr 4 Wilno, d. 8 marca 1920.

${ }^{31}$ CAW WBH DOE Mińsk 1 „e” I. 331. 12. 1, Zarząd Kwaterunkowo-Budowlany przy D.O.E. Mińsk L.: 871 Do Kwatermistrzostwa Frontu Lit.-Białor. Mińsk, dn. 13 lutego 1920 r. w Wilnie.

32 S. MireK, op. cit., s. 93.

33 CAW WBH, Dow. 3 Dyonu Żand. Pol. Etap. Grodno sygn. I.375.30.1, Dowództwo 4 Dyonu Żandarmerii Polowej Etapowej Grodno, dnia 7. 4.21 Rozkaz nr 28. 
w ogóle, wywózka zaś nieczystości ze śródmieścia odbywała się nieregularnie ${ }^{34}$. Nad stanem sanitarnym miasta po części czuwało stacjonujące tam wojsko, ale nadzorowało ono tylko obiekty zajmowane przez swoje oddziały. W celu utrzymania czystości i zapobieżenia epidemiom wydano rozkaz dla dowódców koszar i komendantów budynków wojskowych we Lwowie i na przedmieściach miasta, na mocy którego należało jak najszybciej przeprowadzić dokładne oczyszczenie zajmowanych kwater. Powstałe wskutek prac śmieci polecono spalać, tak aby powstawała jak najmniejsza ilość odpadów do wywozu. Zabroniono wyrzucania nieczystości z budynków wojskowych na ulice miasta, co wcześniej się zdarzało. Na śmietnisko wyznaczono miejsce u wylotu ulicy św. Marcina, za tzw. Złotym Mostem oraz górę Pilichowską, obok cmentarza żydowskiego ${ }^{35}$.

Warunki naturalne miały znaczny wpływ na służbę polskich formacji tyłowych w okresie wojen o granice odrodzonej Rzeczypospolitej. Oddziały te były wprawdzie w mniejszym stopniu narażone na trudy wojenne niż żołnierze frontowi, ale też specyfika formacji powodowała, że pojedynczy żołnierze ciężej znosili niedogodności swojej służby. Starsi wiekiem, słabszego zdrowia i znacznie gorzej wyposażeni „etapowcy” byli obciążani służbą ponad możliwości nawet zdrowego i silnego człowieka. Formacje te zaopatrywano w ostatniej kolejności, po formacjach liniowych i zapasowych. Jeśli oczywiście wystarczało wyposażenia.

Brak technicznych środków łączności powodował wielokrotnie, że żołnierze formacji pełniących służbę etapową byli zmuszeni pieszo przenosić meldunki do oddalonych od siebie o wiele kilometrów placówek. Również patrolowanie długich odcinków linii kolejowych wymagało odpowiedniego ubrania, którego żołnierze nie posiadali. Zniszczenia wojenne i częste rekwizycje doprowadziły mieszkańców wielu regionów Polski, a zwłaszcza pogranicza, do głodu i ruiny ekonomicznej. Niedożywienie oraz migracje powodowały wybuchy epidemii, przede wszystkim chorób związanych ze spadkiem odporności, głodem i brakiem higieny. Zbyt mała liczba żołnierzy przeznaczona do służby etapowej przyczyniała się do ich przemęczenia i osłabienia, często zapadali więc na choroby.

34 W. Нuвко, Lwów w roku 1920: od stolicy kraju koronnego do miasta wojewódzkiego (życie powszednie miasta i mieszkańców), [w:] Tożsamość galicyjska z perspektywy Polski i Ukrainy, red. P. CzUBIK, Z. МACH, Bielsko-Biała 2008, s. 53.

35 CAW WBH, Dowództwo Etapu WP Lwów 1, sygn. I. 330.4.1, Dowództwo Wojkk Polskich na Galicyę Wschodnią. Ekspozytura Kwatermistrzostwa, Rozkaz nr 3, Lwów, dnia 13. Kwietnia 1919. L. p. 13. - Rozporządzenie w sprawie utrzymania czystości w budynkach wojskowych. 
Szczególną negatywną rolę odgrywały tu operujące wojska oraz wzięci do niewoli jeńcy pochodzący z dalekich rejonów ogarniętej chaosem Rosji. Wzmożone migracje powracających z wygnania cywilów i przemieszczające się wojska przenosiły zachorowania spotykane $\mathrm{w}$ okresie pokoju rzadko lub nieznane wcale. Trudnej sytuacji sprzyjał nieporządek, a wręcz brud panujący w miejscach zakwaterowania oddziałów wojskowych. Dochodziła do tego niedbałość lub niezaradność części oficerów, wśród których zdarzali się i tacy, którzy oficerami być nie powinni.

\section{BIBLIOGRAFIA}

\section{Źródła archiwalne}

Centralne Archiwum Wojskowe w Warszawie

Batalion Wartowniczy 4/IV Kołomyja, sygn. I.333.134.1.

DOE Mińsk 1 „b”, sygn. I.331.12.1.

DOE Mińsk 1 „”, sygn. I.331.12.1.

DOE Mińsk 1 „e, sygn. I.331.12.1.

DOE Wilno 1, sygn. I.331.22.1.

DOE Wołkowysk 2, sygn. I.331.23.2.

Dow. 3 Dyonu Żand. Pol. Etap. Grodno, sygn. I.375.30.1.

Dowództwo Etapu Pokucie i Kołomyja, sygn. I.330.2.1.

Dowództwo Etapu WP Lwów 1, sygn. I.330.4.1.

Dowództwo Powiatu Etapowego Kołomyja, sygn. I.332.60.1.

DPE Kołomyja 1, sygn. I.332.60.1.

DPE Kosów 1, sygn. I.332.61.1.

DPE Równe 1, sygn. I.332.78.1.

Państwowe Archiwum Obwodu Lwowskiego we Lwowie

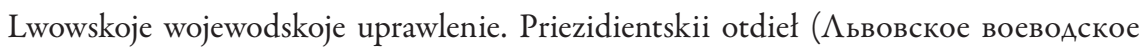
управлене. Презідентскіі отдец), fond 1, opis 57, sprawa 28. 


\section{Opracowania}

Biernacek T., Nad Prutem i Czeremoszem, cz. 1: 1914-1928, Zielona Góra 1992.

Hubko W., Lwów w roku 1920: od stolicy kraju koronnego do miasta wojewódzkiego (życie powszednie miasta i mieszkańców), [w:] Tożsamość galicyjska zperspektywy Polski i Ukrainy, red. P. Czubik, Z. Mach, Bielsko-Biała 2008.

Lis-Błoński S., Batachowcy. Notatki oficera tacznikowego przy Ochotniczej Armii Sprzymierzonej z frontu wojny polsko-bolszewickiej 1920 roku, wstęp i oprac. G.J. Pelica, Kraków 2013.

Mirek S., Opowieści Legionisty. Wspomnienia nie tylko frontowe spisane przez uczestnika walk w Legionach Pitsudskiego, Pruszków 1994.

Odziemkowski J., Piechota polska w wojnie z Rosją bolszewicka 1919-1920, Warszawa 2010.

Odziemkowski J., Polskie formacje etapowe na Litwie i Biatorusi 1919-1920, Kraków 2011.

Okarma H., Wilk. Monografia przyrodniczo-towiecka, Białowieża 1992.

Romer J., Pamiętniki, Warszawa 2011.

Parucki Z., Geografia polityczna i wojenna, Warszawa 1979.

Roguski R., Bezpieczeństwo linii kolejowych na obszarze etapowym Galicji w czasie wojny polsko-ukraińskiej o Galicje Wschodnia w roku 1919, „Studia Historyczno-Wojskowe” 2015, t. 6, s. 135-146.

Roguski R., The protection of the cordon section on the border between Central Lithuania and the so-called Kaunas Lithuania between 1921-1923, „Historia i Świat” 2018, nr 7, s. 247-258.

Rafał Roguski

\section{THE INFLUENCE OF NATURAL CONDITIONS ON THE SERVICE OF REAR FORMATIONS OF THE POLISH ARMY DURING THE POLISH-SOVIET WAR IN 1919-1921}

Summary. In the following article, the author will present the impact of terrain on the service and condition of soldiers stationed in the front, in the so-called stage area. The author will also present the problem of infectious diseases troubling soldiers serving in the back of the front line. The work was based primarily on the archival materials from the Central Military Archives in Warsaw, created by the Command of the Stage Districts and the Command of the Stage Poviats from the period of wars for the borders of Poland 1919-1921.

Keywords: Polish-Soviet war, 1919-1921, army, natural conditions, Poland 